\title{
Pelatihan Penulisan Jurnal Ilmiah untuk Civitas Akademika Universitas Brawijaya Malang
}

\author{
Ibnu Hajar'; Martin C. Fatah ${ }^{2}$; Edy Ispranyoto ${ }^{3}$; Agus Yogiyanto ${ }^{4}$; \\ Yuliansyah $^{5}$; Supriadi Legino ${ }^{6}$ \\ 1, 2, 3, 4, 5, ${ }^{6}$ Fakultas Ketenagalistrikan dan Energi Terbarukan, Institut Teknologi PLN \\ ${ }^{1}$ ibnu.hajar@itpln.ac.id
}

\begin{abstract}
In high education, scientific journal has an important role in advancing the development of sciences as well as career development for researchers and academics. For the academics community (lecturer, researcher, and student), of course they have to do research. After research finished, and then it will be finished to do a research report. The research report has varying forms. For lecturer research it is usually in the form of a research report, while research report as an end product from every high education level, it can be a thesis, or dissertation. For widely publication of a result of research, a research report can be made in a article that it can be published in reputable scientific journal both nasionally and internationally. But generally, most academics community do not / have not thought about doing research and then the results of their research are written and published in the form of a journal. It is right that several difficulties that faced akademics community in writing a scientific journal such as lazy, don't know (there is no idea) about what will be written, there is a idea but don't know how to start it, and various other reason. Therefore, various obstacles, and difficulties they faced in writing a scientific journal, the team of community services (PKM) of Electrical Engineering, IT-PLN Jakarta offer a solution i.e workshop in writing scientific journal through community service activities. This workshop has been carried out due to cooperation with our partner that is Machanical Engineering Department, Engineering Faculity, Brawijaya University. Our partner Brawijaya University prepared participants and workshop venue. The implementation of this workshop in writing scientific journal received a very good response from the participants and provide motivation to them to do research which is then published in the form of scientific journal articles.
\end{abstract}

Keywords: research, scientific journal, community service

\begin{abstract}
ABSTRAK
Dalam dunia pendidikan tinggi, jurnal ilmiah memiliki peran yang sangat penting dalam memajukan pengembangan ilmu pengetahuan maupun pengembangan karir peneliti dan akademisi. Bagi sivitas akademika (dosen, peneliti dan mahasiswa), tentunya diwajibkan melakukan penelitian. Setelah penelitian selesai, maka akan diakhiri dengan membuat laporan penelitian yang bentuknya dapat bermacam-macam. Untuk penelitian dosen biasanya berbentuk laporan penelitian, sedangkan laporan penelitian sebagai suatu produk akhir dari suatu jenjang pendidikan, dapat berupa skripsi, tesis, atau disertasi. Untuk publikasi yang lebih luas dari hasil penelitian, laporan penelitian dapat dibuat dalam bentuk artikel jurnal yang dapat dipublikasikan pada jurnal ilmiah yang bereputasi baik nasional maupun internasional. Namun umumnya, kebanyakan civitas akademika tidak/belum terpikirkan untuk melakukan penelitian untuk kemudian hasil penelitiannya ditulis dan dipublikasi dalam bentuk jurnal. Benar bahwa beberapa kesulitan yang dihadapi civitas akademika dalam menulis jurnal ilmiah antara lain: malas, tidak tahu (tidak ada ide) tentang apa yang akan ditulis, ada ide tapi tidak tahu bagaimana memulainya, dan berbagai macam alasan lain. Oleh karena itu, berbagai kendala, hambatan dan kesulitan tersebut, tim PKM Teknik Elektro, IT-PLN Jakarta menawarkan solusi melalui pelatihan menulis jurnal ilmiah melalui kegiatan pengabdian kepada masyarakat. Pelatihan ini telah terlaksana berkat kerja sama dengan mitra kerja kami yaitu Jurusan Teknik Mesin, Fakultas Teknik, Universitas Brawijaya sebagai mitra yang menyediakan peserta dan
\end{abstract}


Terang: Jurnal Pengabdian Pada Masyarakat Menerangi Negeri

e-ISSN: $2655-5948$

Vol. 2, No. 2, Juli 2020

P-ISSN: 2655-5956

DOI: https://doi.org/10.33322/terang.v2i2.372

Hal. 90 - 99

tempat pelatihan. Pelaksanaan pelatihan penulisan jurnal ilmiah mendapatkan respon yang sangat baik dari peserta dan memberikan motivasi kepada peserta untuk melakukan penelitian yang kemudian dipublikasikan dalam bentuk artikel jurnal ilmiah.

Kata Kunci: Penelitian, Jurnal Ilmiah, Pengabdian Kepada Masyarakat (PKM) 


\section{PENDAHULUAN}

Menulis pada jurnal ilmiah bagi sebagian orang merupakan suatu aktifitas yang kurang diminati di Indonesia, kecuali bagi tenaga pengajar seperti pengajar perguruan tinggi yang dituntut untuk selalu memiliki karya tulis yang terpublikasi pada jurnal atau majalah ilmiah sebagai bagian dari pelaksanaan Tri Darma Perguruan Tinggi. Pun demikian, saat ini salah satu syarat kelulusan mahasiswa mulai dari jenjang strata satu sampai tiga adalah diwajibkan untuk memiliki publikasi karya pada jurnal ilmiah [1].

Dalam dunia pendidikan tinggi, jurnal ilmiah memiliki peran yang sangat penting dalam memajukan pengembangan ilmu pengetahuan maupun pengembangan karir peneliti dan akademisi. Bagi sivitas akademika (dosen peneliti dan mahasiswa), tentunya diwajibkan melakukan penelitian. Setelah penelitian selesai, maka akan diakhiri dengan membuat laporan penelitian yang bentuknya dapat bermacam-macam. Untuk penelitian dosen biasanya berbentuk laporan penelitian, sedangkan laporan penelitian sebagai suatu produk akhir dari suatu jenjang pendidikan, dapat berupa skripsi, tesis, atau disertasi [2].

Karya ilmiah merupakan hasil tulisan yang berisi pengetahuan, informasi dan ilmu yang didapatkan melalui sebuah studi baik lapangan maupun pustaka. Karya ilmiah bukanlah karya yang sifatnya asal jadi, mengingat karya tersebut akan menjadi konsumsi masyarakat. Karya tersebut harus terpercaya dan bukan hasil rekayasa [3].

Berdasarkan hal tersebut di atas, maka dunia akademik merupakan dunia yang paling potensial untuk melahirkan karya ilmiah yang berkualitas. Dunia akademik yang dimaksud adalah dosen dan mahasiswa. Mahasiswa sebagai bagian dari lingkungan akademis tersebut sangat diharapkan mampu melakukan kegiatan menulis secara rutin, sehingga dapat melahirkan karya tulis baik karya tulis ilmiah seperti buku dan jurnal maupun karya tulis ilmiah populer seperti artikel. Tulisan-tulisan yang berisi informasi pengetahuan tersebut akan menjadi simbol (media) pengembangan ilmu pengetahuan yang efektif bagi masyarakat dibandingkan dengan berbicara [3].

Pada kenyataannya, kegiatan menulis dikalangan mahasiswa Indonesia belum membudaya. Jumlah karya ilmiah yang dihasilkan sebuah perguruan tinggi masih jauh dari harapan. Berbagai alasan dan hambatan dikemukakan oleh mahasiswa sehingga tidak melakukan aktifitas menulis. Tidak berbakat, kurang motivasi, tidak ada waktu, kurang referensi adalah bagian dari alasan tersebut [3].

Meskipun demikian, tidak dapat dipungkiri bahwa kegiatan menulis ilmiah bukanlah suatu aktifitas yang dapat dilakukan secara spontanitas. Seorang penulis sekurang-kurangnya harus memahami dengan jelas apa yang disebut dengan tulisan ilmiah dan segala bentuk kaidah penulisannya. Selain itu, kegiatan menulis memerlukan banyak latihan, dilakukan berulang-ulang secara berkesinambungan sehingga menghasilkan suatu karya ilmiah yang layak dipublikasikan [4], [1].

Menulis karya ilmiah memiliki beberapa tahap dan prosedur yang harus dilalui seperti mencari ide dengan membaca, melakukan pengamatan, mengadakan penelitian, melakukan eksperimen, menemukan data dan teori pendukung dan selanjutnya menuliskan hasil. Selain itu, dalam penulisan karya ilmiah juga harus memenuhi kaidah penulisan bahasa ilmiah seperti penggunaan tata bahasa baku, pemilihan kata dan efektifitas penulisan [4].

Karena itu, dengan memahami kondisi yang banyak dialami oleh civitas akademika tersebut di atas, maka pelatihan penulisan artikel jurnal ilmiah ini akan memberikan pengetahuan yang dibutuhkan dalam penulisan artikel jurnal ilmiah dan tentunya akan sangat bermanfaat bagi mahasiswa, dosen dan peneliti. 
Berbeda dengan target peserta sebelumnya yang ada pada proposal PKM yaitu mahasiswa $S 1$ tingkat akhir yang akan menyelesaikan studinya dengan menyusun skripsi dan menulis jurnal ilmiah. Pada pelaksanaan kegiatan peserta pelatihan didominasi yang berasal mahasiswa S3 dan dosen dan mungkin hanya sedikit mahasiswa S2, sehingga pelatihan ini benar-benar memberikan kejutan yang luar biasa pada tim pelaksana kegiatan PKM.

Bagi mahasiswa S3, mereka tidak akan bisa maju sidang disertasi apabila tidak memiliki publikasi jurnal ilmiah terindeks scopus minimal satu jurnal, sehingga merupakan tantangan bagi mereka untuk mengejar publikasi jurnal ilmiah terindeks scopus.

Bagi dosen peneliti adalah merupakan pelaksanaan Tri Darma Perguruan Tinggi untuk melakukan penelitian dan hasil penelitiannya wajib dipublikasikan pada jurnal ilmiah untuk menaikkan credit point (cum) mereka, sehingga akan berpengaruh pada kemajuan kepangkatan atau jabatan fungsional dosen.

Dengan permasalahan-permasalahan mitra yang disebutkan di atas diharapkan dengan pelatihan penulisan jurnal ilmiah ini memberikan motivasi dan menguatkan tekat mahasiswa S3 dan dosen untuk menulis jurnal ilmiah dan dapat memudahkan mereka untuk menembus jurnal ilmiah terakreditasi scopus.

\section{METODE PELAKSANAAN}

Metode yang digunakan untuk menjawab permasalahan atau mencapai tujuan kegiatan program pengabdian pada masyarakat (P2M) ini adalah dengan melakukan pelatihan melalui tahaptahap sebagai berikut:

1. Persiapan

Persiapan dilakukan dengan mengadakan kesepakatan kerjasama dengan mitra, yaitu antara Tim P2M Teknik Elektro Sekolah Tinggi Teknik PLN dengan Ketua Jurusan Teknik Mesin, Universitas Brawijaya Malang. Universitas Brawijaya berkewajiban menyiapkan dan mengorganisir peserta pelatihan dan termasuk mempersiapkan tempat pelatihan yaitu ruang sidang Jurusan Teknik Mesin, sedangkan kewajiban Tim P2M Teknik Elektro Sekolah Tinggi Teknik PLN berkewajiban mempersiapkan materi dan pelaksanaan pelatihan ini.

2. Pelaksanaan

Pelaksanaan pelatihan di Ruang Sidang Jurusan Teknik Mesin, Fakultas Teknik, Universitas Brawijaya Malang yang diikuti oleh \pm 150 peserta pelatihan yang terdiri dari dosen, mahasiswa S3 dan S2. Pelatihan diawali dengan penyampain materi oleh dosen Jurusan Teknik Mesin dan kemudian dilanjutkan tim dosen pengabdian, dan setiap selesai materi oleh pemateri langsung diadakan tanya jawab.

Pelaksanaan pelatihan sesuai kesepakatan mitra dengan tim pelaksana pengabdian, dibutuhkan waktu minimum 3 hari kerja.

Materi pelatihan adalah sebagai berikut:

a. Materi oleh Prof. Dr. Ir. Wardana

b. Materi "Writing A Paper for International Journal" oleh Martin C. Fatah, PhD.

c. Materi "Listrik Kerakyatan" oleh Ir. Edy Ispranyoto, MBA. 


\section{HASIL DAN PEMBAHASAN}

\subsection{Hasil Yang Dicapai}

Pelatihan penulisan artikel jurnal ilmiah ini mendapatkan sambutan luar biasa dari peserta. Hal tersebut terlihat dari banyak peserta yang mengikuti pelatihan ini yaitu lebih kurang 150 peserta yang teridiri dari dosen - peneliti dan mahasiswa S2 dan S3.

Hasil yang dicapai dari kegiatan Program Kemitraan Masyarakat Pelatihan Penulisan Jurnal Ilmiah untuk Civitas Akademika Jurusan Teknik Mesin, Fakultas Teknik, Universitas Brawijaya adalah:

a. Bagi kelompok sasaran, mendapatkan pengetahuan yang dalam bagaimana menulis jurnal ilmiah yang baik dan benar sehingga memudahkan jurnal ilmiah mereka dapat diterima pada publikasi jurnal ilmiah terakreditasi scopus. Dan mendapatkan motivasi bagi peserta pelatihan penulisan jurnal untuk lebih semangat menghasilkan tulisan-tulisan yang akan dipublikasikan di jurnal ilmiah.

b. Bagi Tim PKM, mempraktekkan ilmu dan keterampilan yang dimiliki khususnya dalam bidang penulisan jurnal ilmiah.

c. Bagi IT-PLN, memperluas jaringan dan kerjasama antar perguruan tinggi dalam bentuk kerjasama penelitian dan pengabdian kepada masyarakat, yaitu dengan dimintanya salah satu anggota tim PKM untuk menjadi reviewer pada jurnal yang diterbitkan oleh Jurusan Teknik Mesin, Fakultas Teknik, Universitas Brawijaya.

\subsection{Pembahasan}

\subsubsection{Persiapan Sebelum Menulis Artikel Jurnal Ilmiah}

Sebelum memulai menulis artikel ilmiah, diperlukan adanya persiapan yang matang. Persiapan tersebut termasuk persiapan mental, keterampilan dan teknis, serta sarana-prasarana. Persiapan mental meliputi antara lain motivasi dan daya tahan. Motivasi terbaik untuk menulis artikel ilmiah harus datang dari diri sendiri, walaupun dorongan dari lingkungan sekitar juga cukup berperan penting. Persiapan keterampilan dan teknis mencakup pengetahuan tentang tata-tulis dan bahasa, baik bahasa asing maupun bahasa Indonesia (terutama EYD) dan teknik parafrasing untuk menghindari plagiarisme. Selain itu, diperlukan juga keterampilan menggunakan komputer, baik untuk menganalisis data, membuat ilustrasi dan menulisnya (word processing) itu sendiri, maupun untuk mengakses internet - mencari kepustakaan pendukung terkini [2].

Dalam pelatihan ini, pembahasan difokuskan ke persiapan teknis menulis jurnal ilmiah dengan asumsi bahwa persiapan mental dan persiapan sarana prasarana sudah tidak ada masalah. Persiapan yang perlu dilakukan sebelum menulis artikel jurnal ilmiah adalah seperti berikut [2],

a. Mengikuti pelatihan penulisan jurnal ilmiah (atau berdiskusi dengan pakar penulisan jurnal ilmiah.

b. Membaca jurnal-jurnal ilmiah yang terkait dibidang ilmu kita

c. Menetapkan jurnal ilmiah yang akan kita kirimi artikel ilmiah

d. Mendapatkan petunjuk penulisan jurnal ilmiah tersebut dan salah satu contoh jurnalnya

e. Mengecek ulang data penelitian kita (Analisis, metode, penyajian, dlsb)

f. Menjamin tidak akan ada masalah kepemilikan hak atas jurnal ilmiah yang akan diterbitkan 


\subsubsection{Pelaksanaan Penulisan Artikel Jurnal Ilmiah}

Format baku bagian inti dari suatu artikel jurnal ilmiah dikenal dengan sebutan IMRaD yang merukan singkatan dari Introduction (Pendahuluan), Material and Method (Bahan dan Metode), Result (Hasil) and Discussion (Diskusi atau Pembahasan). Pada sebagian jurnal, bagian Hasil digabungkan dengan Pembahasan sebagai "Hasil dan Pembahasan" [2].

Penulis artikel jurnal internasional kriteria yang harus diperhatikan adalah bahwa jurnal tersebut memiliki ISSN, ditulis dalam bahasa resmi PBB (yaitu Inggris, Prancis, Arab, Rusia dan Cina), Dewan editor terdiri dari orang-orang terkemuka dibidangnya dan berasal dari beberapa negara, artikel yang diterbitkan dalam satu masalah ditulis oleh penulis dari berbagai negara [5].

Beberapa hal yang dapat dijadikan alat atau patokan bagi penulis artikel dalam menyeleksi jurnal yang akan dituju, misalnya adalah [5],

- Metrik sitasi (kutipan), banyak digunakan sebagai ukuran kualitas bagi pustakawan, penulis, peneliti dan penerbit.

- Dalam bentuk yang paling sederhana, menghitung jumlah rata-rata sitasi selama periode waktu tertentu, seperti impact factor / Social Sciences Citation Index, SNIP/Scopus, Eigen factor score journal

- Scimago Journal and Country Rank (SJR)

- Dan banyak faktor yang perlu dipertimbangkan ketika memutuskan jurnal mana yang tepat untuk tempat publikasi jurnal.

Dalam penulisan jurnal internasional, penelitian yang baik dan penulisan yang bagus yaitu terkait penulisan dalam bahasa Inggris dan struktur bahasa yang baik adalah persyaratan penting yang harus terpenuhi. Yang dimaksud penelitian yang baik yaitu dilakukan berdasarkan kompetensi peneliti, kontribusi dan atau kebaruan penelitian (topik dan metodologi), dan metodologi penelitian terkini [5].

Isi artikel pada suatu jurnal ilmiah diberikan secara singkat berikut ini [5],

a. Judul, harus merepresentasikan isi dari artikel yaitu menuliskan apa yang baru / apa yang membuat jika berbeda di awal, menggambarkan masalah utama yang akan pecahkan, benar-jelas-sempurna-ringkas, menentukan pembaca akan melanjutkan membaca artikel atau tidak.

b. Abstrak, ringkasan dari penelitian/tulisan yang terdiri dari latar belakang, tujuan, metodologi, hasil dan kesimpulan.

c. Pendahuluan, memulai dari konten yang luas, menggambarkan kepada pembaca apa yang sudah diketahui, menggambarkan apa yang belum diketahui atau ada masalah apa, menggambarkan apa yang penulis putuskan untuk dilakukan, dan menulis tujuan penelitian.

d. Metodologi, menggambarkan material atau bahan-bahan apa yang digunakan dalam penelitian, menjelaskan bagaimana material tersebut dipersiapkan untuk penelitian, menggambarkan protokol penelitian, menjelaskan bagaimana pengukuran dibuat dan perhitungan apa yang dilakukan, menyebutkan uji statistik mana yang dilakukan.

e. Hasil dan Pembahasan, melihat kembali tujuan penelitian dan membandingkan dengan grapik dan table yang didapatkan, membandingkan dengan materi lain yang diterbitkan, mendiskusikan secara khusus perbedaan hasil, menjelaskan temuan, mendiskusikan implikasi temuan, menjelaskan batasan dan bias, dan menjelaskan kekuatan dan kelemahan dalam hubungannya dengan yang lain.

f. Kesimpulan, menjelaskan bagaimana penelitian telah menggerakan pengetahuan ilmiah ke depan, terdiri dari apa yang dipelajari, dan jawaban terhadap tujuan penelitian (jumlah kesimpulan harus sama atau lebih dari tujuan penelitian) 
g. Ucapan terima kasih kepada semua pihak terkait yang telah berkontribusi pada penelitian.

h. Referensi atau daftar pustaka, gunakan EndNote (atau software lain) jika mungkin, kutip beberapa pekerjaan supervisor dan pekerjaan peneliti, kutip makalah-makalah penting, ikuti petunjuk jurnal, dan kutip makalah terbaru.

Bagi penulis artikel harus memperhatikan etika berikut yaitu waspada terhadap plagiarisme diri sendiri, tidak mensubmit satu artikel kepada lebih dari satu jurnal pada waktu yang sama, tidak mengirim artikel yang tidak selesai hanya untuk mendapatkan umpan balik, selalu sertakan dan / atau mengakui semua penulis bersama (dan biarkan mereka tahu penulis telah mensubmit makalah untuk dipublish, selalu menyebutkan sumber pendanaan penelitian, jika menggunakan data yang dikumpulkan oleh orang lain pastikan bahwa anda mempunyai izin menggunakannya dalam artikel peneliti [5].

Berikut ini adalah dokumentasi foto kegiatan pengabdian:

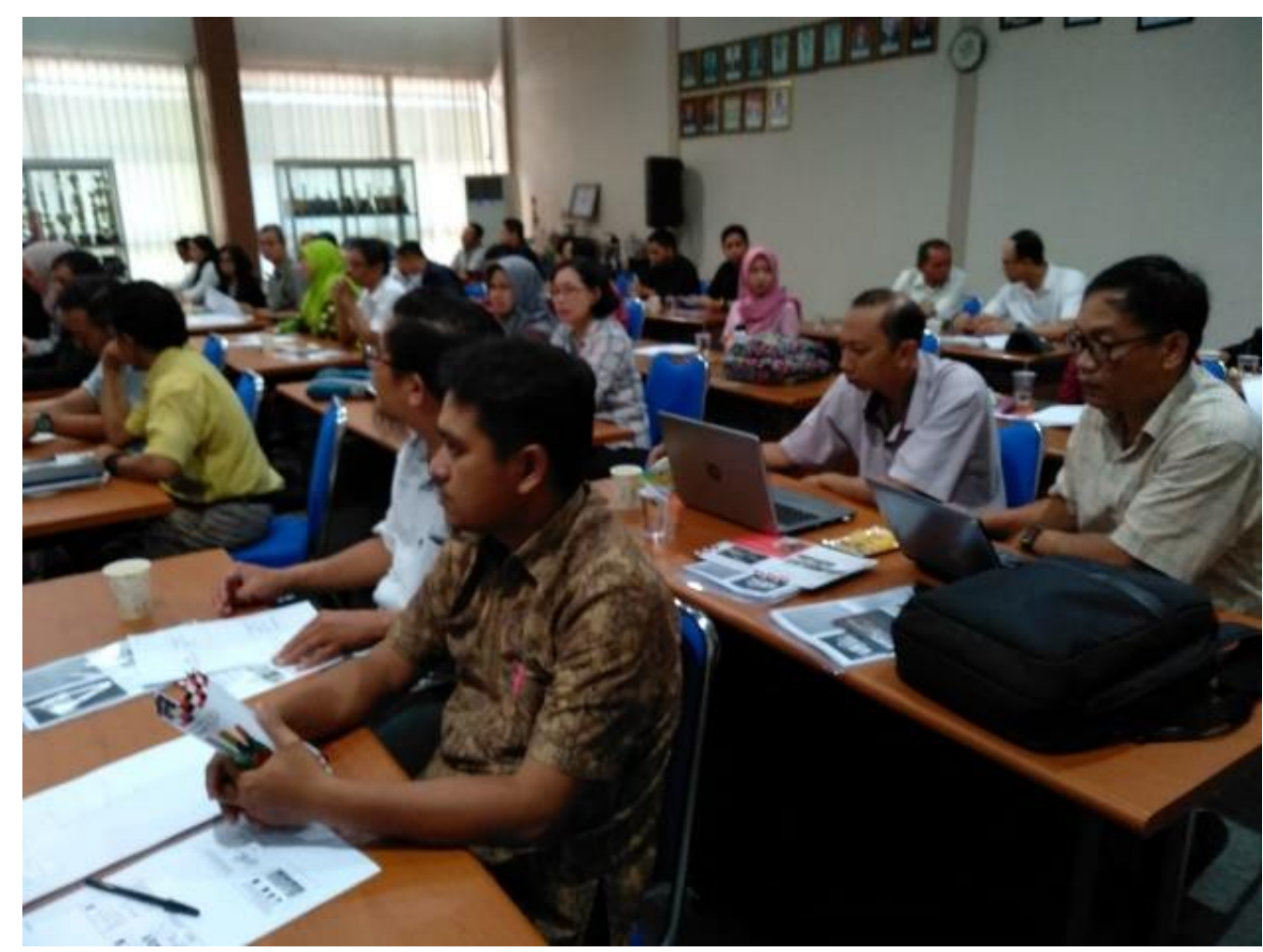

Gambar 1. Suasana Peserta Pelatihan Pada Saat Menerima Materi 
Terang: Jurnal Pengabdian Pada Masyarakat Menerangi Negeri

e-ISSN: 2655-5948

Vol. 2, No. 2, Juli 2020

P-ISSN: 2655-5956

DOI: https://doi.org/10.33322/terang.v2i2.372

Hal. 90 - 99

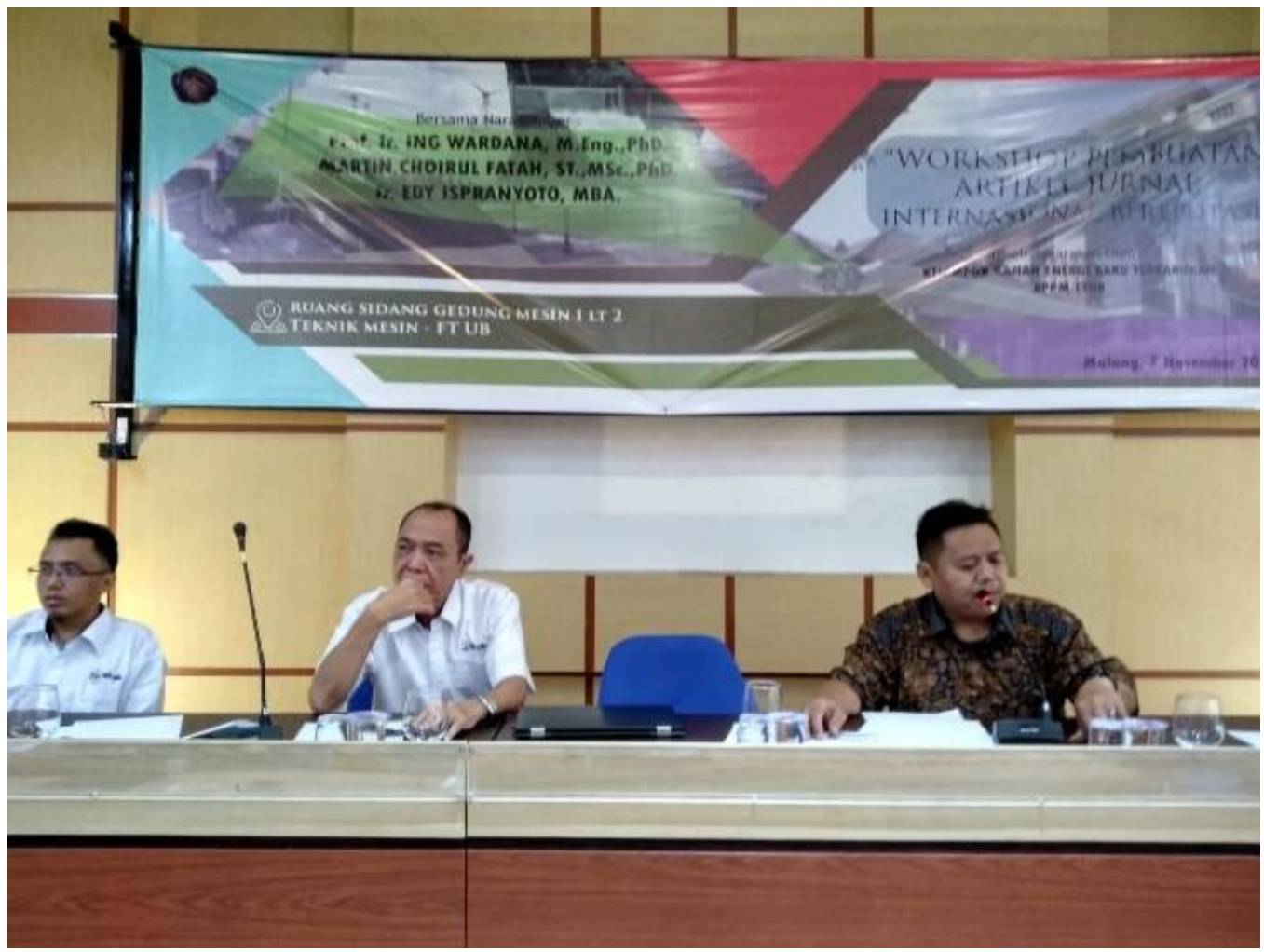

Gambar 2. Pemateri dan Moderator
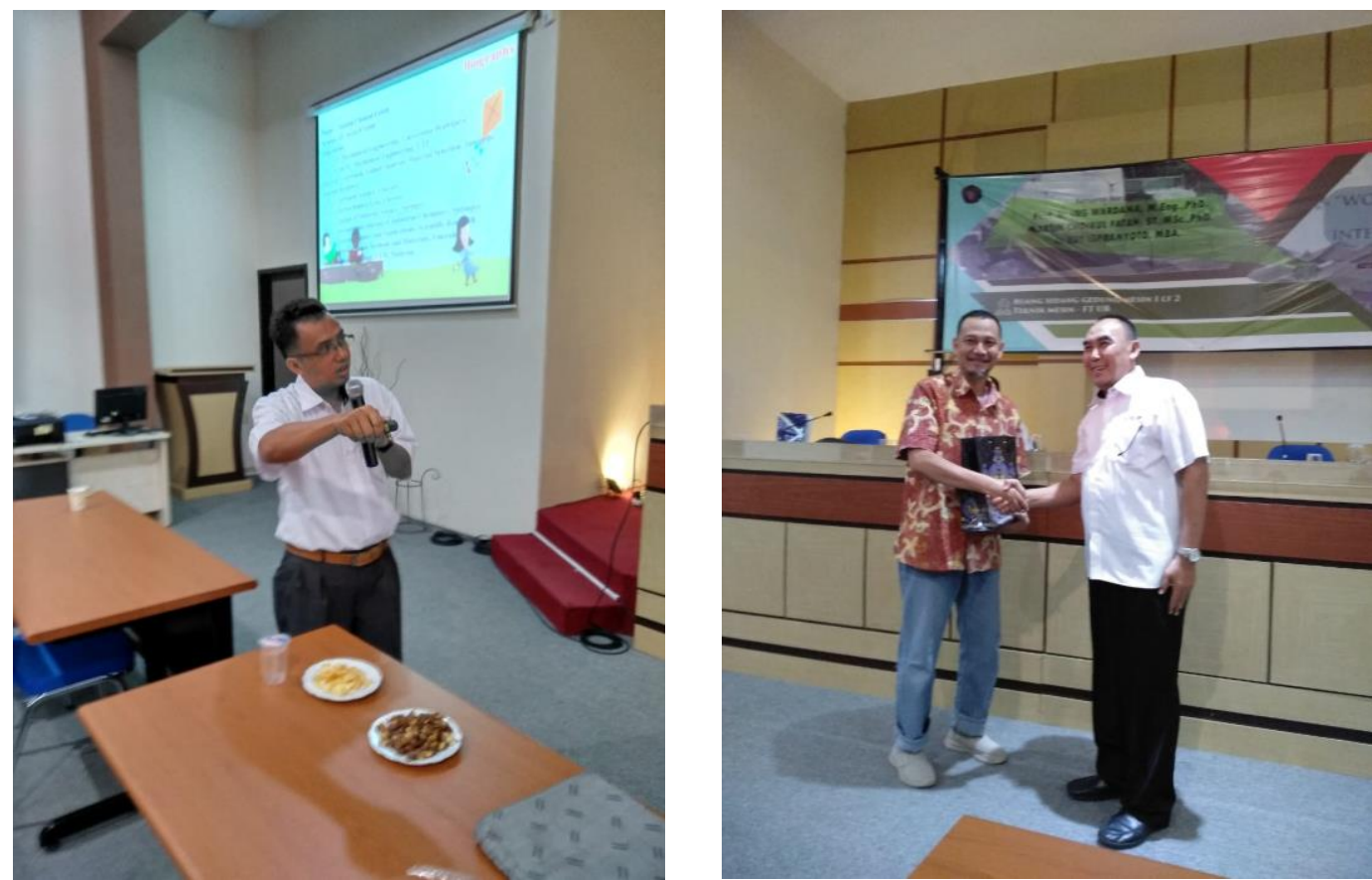

Gambar 3. Pemateri Memberikan Materinya dan Pemberian Cendramata 


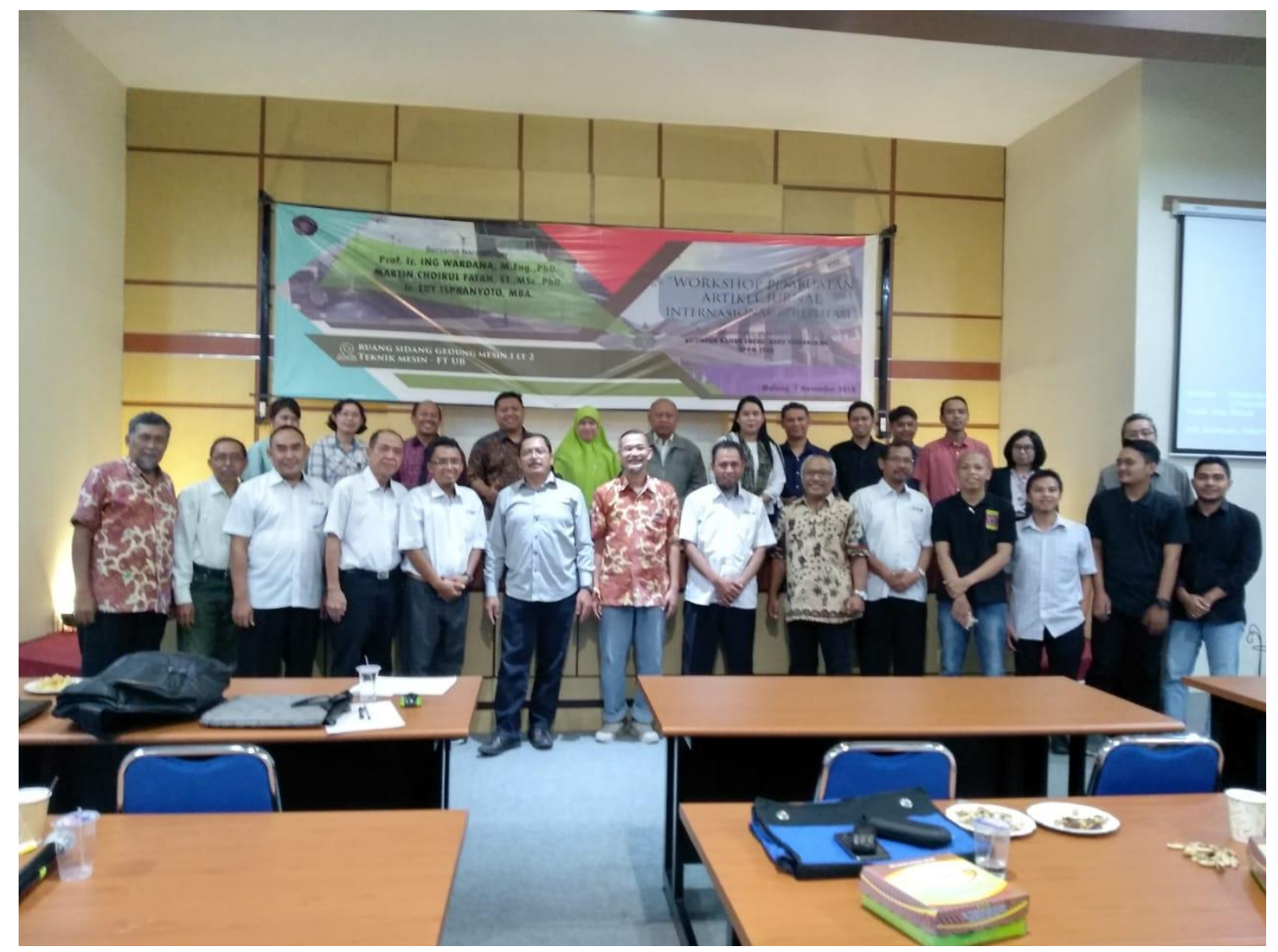

Gambar 4. Tim PKM bersama dosen UB dan peserta

\section{KESIMPULAN}

Dari kegiatan Pengabdian Kepada Masyarakat yang telah dilakukan maka dapat diambil kesimpulan bahwa pelaksanaan kegiatan ini memberikan nilai tambah bagi civitas akademika Jurusan Teknik Mesin, Fakultas Teknik, Universitas Brawijaya yaitu nilai tambah pengetahuan tentang kiat-kiat penulisan jurnal ilmiah yang baik dan benar dan menambah motivasi bagi peserta pelatihan untuk selalu melakukan kegiatan menulis pada jurnal ilmiah. Selain itu, terjalin kerja sama antar perguruan tinggi dalam bentuk kerjasama penelitian dan pengabdian pada masyarakat, dalam hal ini antara IT-PLN dan Jurusan Teknik Mesin, Fakultas Teknik, Universitas Brawijaya.

\section{SARAN}

Kegiatan pelatihan penulisan jurnal ilmiah bagi civitas akademika perguruan tinggi sangat perlu terus dilakukan dan ditingkatkan karena mengingat kesadaran bagi civitas akademika dalam hal penulisan pada jurnal ilmiah masih sangat rendah dibandingkan dengan negara-negara tetangga misalnya Malaysia. Malaysia sudah sangat jauh mengungguli Indonesia dalam hal publikasi jurnal ilmiah internasional. Maka, dengan pelatihan penulisan jurnal ilmiah bisa menambah giroh/kesadaran bagi civitas akademika untuk selalu memperbanyak tulisan-tulisan mereka untuk publikasi jurnal ilmiah baik nasional maupun internasional. 


\section{UCAPAN TERIMA KASIH}

Terima kasih kami sampaikan kepada instansi IT-PLN Jakarta yang telah mendanai kegiatan Pengabadian Kepada Masyarakat (PKM) ini melalui Lembaga Pengabdian Pada Masyarakat (LPPPM).

\section{DAFTAR PUSTAKA}

[1] M. Utami Dewi, "Jurnal Ilmiah: Mengapa dan Bagaimana," FORBI HIMA Ilmu Admistrasi Negara, 2012.

[2] T. Suganda, "Research Gate," 10 May 2014. [Online]. Available: https://www.researchgate.net/publication/262561789. [Diakses 13 September 2018].

[3] Rahmiati, "Analisis Kendala Internal Mahasiswa Dalam Menulis Karya Ilmiah," Al Daulah, vol. 3, no. 2, pp. 254-269, 2014.

[4] Rahmiati, "Problematikan Mahasiswa Dalam Menulis Karya Ilmiah," Jurnal Adabiyah, vol. XIII, no. 2, pp. 160-175, 2013.

[5] M. C. Fatah, "Writing A Paper for International Journal," Malang, 2018. 